\title{
Ecological role and bacterial grazing of Halteria spp.: small freshwater oligotrichs as dominant pelagic ciliate bacterivores
}

\author{
Karel Šimek ${ }^{1,2, *}$, Klaus Jürgens ${ }^{3}$, Jiř́i Nedoma ${ }^{1}$, Marta Comerma ${ }^{4}$, Joan Armengol ${ }^{4}$ \\ ${ }^{1}$ Hydrobiological Institute of the Academy of Sciences of the Czech Republic, and ${ }^{2}$ Faculty of Biological Sciences, \\ University of South Bohemia, Na sádkách 7, 37005 České Budějovice, Czech Republic \\ ${ }^{3}$ Max Planck Institute of Limnology, PO Box 165, 24302 Plön, Germany \\ ${ }^{4}$ Department of Ecology, University of Barcelona, Av. Diagonal 645, 08028 Barcelona, Spain
}

\begin{abstract}
We conducted extensive studies on bacterivory and bacterial production over several seasons in 2 reservoirs: the meso-eutrophic Rímov Reservoir in the Czech Republic and the highly eutrophic Sau Reservoir in Spain. Based on abundance, seasonal dynamics, and cell-specific uptake rates of different ciliate taxa, as well as heterotrophic nanoflagellate bacterivory, we were able to quantify bacterivory by individual ciliate species, total ciliates, and aggregated protists in these systems. With increasing trophic status, a higher portion of bacterial production was consumed by protists, and there was a greater importance of ciliate grazing, accounting for 40 and $50 \%$ of the total protistan bacterivory in the epilimnion of the Řimov and Sau reservoirs, respectively. Increases were attributable to the oligotrichs of the genus Halteria that often numerically dominate freshwater pelagic ciliate communities. In both reservoirs, the most important ciliate bacterivores in order of importance were: oligotrichs, primarily the bacterivorous Halteria spp., peritrichs, and scuticociliates. We also examined food vacuole content in natural populations of Halteria spp. to estimate the proportion of cells that had ingested algae. Our results and a review of previous reports on the abundance of Halteria spp. suggest that small halteriids are ecologically important bacterial consumers in meso- to eutrophic freshwater systems due to: (1) efficient uptake of prey over a large size spectrum (approximately 0.4 to $5 \mu \mathrm{m}$ ), (2) high clearance rates on picoplankton-sized particles along with (3) high potential growth rate, and (4) lower vulnerability to metazooplankton predation compared to other common pelagic ciliates. Correspondingly, we suggest a revised concept of planktonic ciliate bacterivory, where the principal role is attributed to small omnivorous filter-feeding oligotrichous ciliates.
\end{abstract}

KEY WORDS: Halteria cf. grandinella $\cdot$ Oligotrichous ciliates · Feeding rates · Feeding ecology · Ciliate bacterivory $\cdot$ Reservoirs $\cdot$ Lakes

Resale or republication not permitted without written consent of the publisher

\section{INTRODUCTION}

Abundance and biomass of planktonic ciliates are related to lake trophic status, as measured by chlorophyll a concentrations (e.g., Beaver \& Crisman 1989, Müller 1989, Carrias et al. 1998). In a review paper, Beaver \& Crisman (1989) concluded that taxonomic replacements occur with increasing eutrophication such that large-bodied forms (predominantly oligotrichs) are progressively replaced by smaller-bodied

*E-mail: ksimek@hbu.cas.cz ciliates (mainly scuticociliates). However, recent studies of temperate meso- and eutrophic lakes have shown that pelagic ciliate communities are often dominated by small $(<30 \mu \mathrm{m})$ species, mainly oligotrichs and prostomatids (e.g., Müller 1989, Macek et al 1996), while scuticociliates, haptorids, and peritrichs are usually less numerous.

Small heterotrophic nanoflagellates have been reported as the major consumers of bacterioplankton production in most aquatic systems (e.g., Fenchel 1982, Güde 1986, Sanders et al. 1989). However, there is increasing evidence that ciliates can also significantly 
contribute to total protistan bacterivory (e.g., Sherr \& Sherr 1987, Šimek et al. 1995, 1998a). Studies of taxonspecific bacterivory have shown that among pelagic ciliates the most important consumers of bacterioplankton production in both marine and freshwaters are often small oligotrichs (Sherr \& Sherr 1987, Sanders et al. 1989, Šimek et al. 1995, 1996, Stabell 1996, Hwang \& Heath 1997a, Thouvenot et al. 1999), rather than bacterivorous species such as scuticociliates, which usually require bacterial concentrations higher than those found in most pelagic environments (e.g., Fenchel 1980). Such high bacterial abundances are found in hypertrophic systems which can support large populations of scuticociliates (mostly of the genera Cyclidium and Uronema, e.g., Nakano et al. 1998) or in specific environments, such as the chemocline, oxycline, etc. (Fenchel et al. 1990). Only occasionally are small scuticociliates, e.g., Cyclidium spp., found to be important bacterivores in the pelagial of meso- and eutrophic systems, probably due to micropatches such as organic aggregates that have high bacterial densities (Šimek et al. 1995, 1998b).

Among small oligotrichs, the genus Halteria, most probably the species $H$. grandinella, has been identified as an abundant bacterial consumer in several meso- and eutrophic lakes and ponds (Sanders et al. 1989, Šimek et al. 1995, 1998a, Stabell 1996, Nakano et al. 1998). This species has also been studied with respect to taxonomy (e.g., Tamar 1990, Foissner 1994), feeding ecology (Jürgens et al. 1996), and vulnerability to metazooplankton predation (e.g., Tamar 1979, Gilbert 1994, Wiackowski et al. 1994a). Recently it has been reported that the genus Halteria sensu lato comprises several rather similar species. H. grandinella Müller is likely the most important species, but $H$. bifurcata Tamar and Pelagohalteria cirrifera Kahl are quite similar (summary of taxonomic information in Foissner et al. 1999) and cannot always be routinely differentiated in quantitative examinations, as silver impregnations are necessary to examine the somatic ciliature. Thus, since the latter 2 species have been recently found in various European lakes (Foissner pers. comm.), and with respect to the fact that they probably cannot be differentiated in quantitative studies, we pooled these halteriids together and used the term 'Halteria' throughout this paper, being aware that it might contain heterotrophic species of the 2 genera Halteria and Pelagohalteria.

Here we report on abundance, seasonal and spatial dynamics, and cell-specific uptake rates of Halteria, as well as the contributions of different ciliate taxa to total protistan bacterivory in 2 systems. By combining recent and some previously published field data (Šimek et al. 1995) on uptake rates and food vacuole content, with additional laboratory experiments for estimating the rate of ingestion and digestion of typical food items (Jürgens \& Simek 2000, in this issue), we tried to elucidate the most important factors affecting abundance, growth rate, feeding ecology, and carbon requirements of this apparently common and important ciliate species.

\section{MATERIALS AND METHODS}

Sampling. We conducted studies in 2 dam reservoirs, the meso-eutrophic Ŕimov Reservoir and the eutrophic Sau Reservoir. In the Rímov Reservoir (South Bohemia, Czech Republic, for more details see Šmek et al. 1995), the sampling site was located above the former river valley (a $30 \mathrm{~m}$ depth) close to the reservoir dam. Samples were collected from the epilimnion (a mixed sample from $1 \pm 0.5 \mathrm{~m}$ depth) and the metalimnion (a mixed sample from the thermocline $\pm 0.5 \mathrm{~m}$ ) of the reservoir at 2 to $3 \mathrm{~d}$ intervals from August through September 1993 (see Šimek et al. 1995). Additional samples were collected from the surface layer $(1 \mathrm{~m}$ depth) during a Halteria peak at the beginning of October 1994. In 1997, samples were collected from the surface layer (1 $\mathrm{m}$ depth) at 3 to $6 \mathrm{~d}$ intervals during the spring bloom period (late April-May) and clear water phase (June) and sampled at 1 to $3 \mathrm{wk}$ intervals over the rest of the study period.

The eutrophic Sau Reservoir is an $18.5 \mathrm{~km}$ long, canyon-type reservoir located in the middle stretch of the River Ter (Catalonia, NE Spain, for a detailed description see Vidal \& Om 1993). The reservoir was sampled during the period of summer stratification in June-July 1996; samples were collected from 0.5 and $2 \times$ the Secchi depth from 2 stations located about 1.5 and $3 \mathrm{~km}$ from the reservoir dam. During 1997, water samples were collected in 2 intensive sampling campaigns consisting of 9 points (all $\sim 1.8 \mathrm{~km}$ apart; for details see Armengol et al. 1999) along the longitudinal axes of the reservoir: in April, when the temperature of the river inflow was the same as that of the epilimnetic reservoir water $\left(\sim 16^{\circ} \mathrm{C}\right.$, $)$ and in July, with well- developed water stratification (for details see Comerma et al. in press). In both cases mixed water samples from the top $3 \mathrm{~m}$ were collected.

Bacterial abundance, biomass, and production. Subsamples were fixed with formaldehyde (2\% final concentration), stained with DAPI (final concentration $0.2 \% \mathrm{wt} / \mathrm{vol}$ ) and enumerated by epifluorescence microscopy (Olympus BH2 or BX60). Between 400 and 600 DAPI-stained bacterial cells were recorded at a magnification of $1250 \times$ using an analog monochrome LCD camera (Cohu) mounted to the Olympus BX60 microscope. The recorded bacterial cells were then processed with the semiautomatic image analysis 
system LUCIA D (LUCIA 3.52, resolution $750 \times 520$ pixels, 256 grey-levels, Laboratory Imaging, Prague, Czech Republic, http://www.lim.cz). Cell area and cell perimeter were chosen as the most reliable parameters of pixel measurements. Details of the image processing (grey transformation, edge finding) are described in Posch et al. (1997).

Bacterial production was measured by $\left[{ }^{3} \mathrm{H}\right]$-thymidine incorporation using the method modified from Riemann \& Søndergaard (1986); for details, see Šimek et al. (1995). For different sampling periods (see above), corresponding empirical conversion factors (ECF) of thymidine incorporation rate to bacterial cell production were determined by incubating replicate $750 \mathrm{ml}$ subsamples of $1.0 \mu \mathrm{m}$ filtered water for $24 \mathrm{~h}$ at in situ temperature (see Šimek et al. 1995, 1999). In the present study, we applied the following ECF: 2.27 to $2.74,3.0$, and $1.75 \times 10^{18}$ cells mol $^{-1}$ of thymidine incorporated for the Rímov Reservoir in 1993, 1994, and

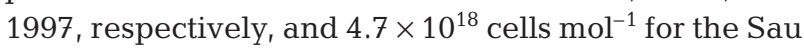
Reservoir in April 1997. A theoretical conversion factor

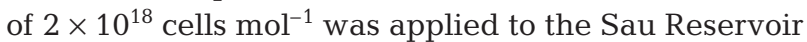
data in July 1997.

Protistan grazing and abundance. To measure protistan grazing on bacterioplankton, we used fluorescently labelled bacterioplankton (FLB) prepared according to Sherr \& Sherr (1993), as slightly modified by Šimek \& Straškrabová (1992). Bacterioplankton from the reservoirs was concentrated on $0.2 \mu \mathrm{m}$ pore-size filters after pre-filtration through $2 \mu \mathrm{m}$ pore-size filters (Poretics). Bacterial cells were detached from the filter surface by several sonication pulses and fluorescently labelled in $\sim 30 \mathrm{ml}$ of a staining solution. This small modification minimized the loss of very small cells, resulting in a good fit of size distributions of bacterioplankton and FLB. Heterotrophic nanoflagellate (HNF) and ciliate FLB uptake rates were determined using $500 \mathrm{ml}$ samples for short-term FLB direct uptake experiments with tracer amounts of FLB (5 to $17 \%$ of natural bacterial concentration). In cases where small oligotrichs were abundant, we used a separate treatment for the ciliates where FLB tracers amounted to $<5 \%$ of bacterial abundance. Subsamples of 30 to $50 \mathrm{ml}$ were taken at $0,3,6,10,20$, and $30 \mathrm{~min}$, or 0,5 , $10,15,20,40$, and $60 \mathrm{~min}$ after tracer addition and fixed by $0.5 \%$ of alkaline Lugol's solution, immediately followed by $2 \%$ borate-buffered formaldehyde (final concentration) and several drops of $3 \%$ sodium thiosulphate to clear the Lugol's color. This preservation technique is recommended to prevent egestion of food particles by HNF (Sherr \& Sherr 1993). Within 3 d after fixation, 5 to $15 \mathrm{ml}$ (flagellates) or 20 to $30 \mathrm{ml}$ (ciliates) subsamples were stained with DAPI, filtered through 1 (HNF) or $2 \mu \mathrm{m}$ (ciliates) black polycarbonate filters (Poretics), and the protozoa inspected and counted on the filters via epifluorescence microscopy (Šimek et al. 1995, 1997). Up to $200 \mathrm{HNF}$ and 50 to 100 ciliates were inspected at randomly selected microscopic fields at each time point. Non-pigmented, HNF and plastidic flagellates were always differentiated. Ciliate uptake rates as FLB cell ${ }^{-1}$ were estimated at 3, 6, and 10 min, or alternatively at 5, 10, and 15 min exposure. HNF uptake rates were estimated at 10,20, and $30 \mathrm{~min}$, or alternatively at 20,40, and $60 \mathrm{~min}$; the longer times were used during cold water periods. Samples from time zero were also inspected to avoid potential bias of our data due to attachment of non-ingested tracers on protozoan surfaces. Uptake rates were calculated by linear regression of average number of tracers per protozoan cell versus time. To estimate total protistan grazing rate, average grazing rates of HNF and ciliates were multiplied by their total in situ abundances.

Community structure of ciliates. Ciliate community structure was evaluated by combining: (1) DAPIstained samples in epifluorescence microscopy, (2) live sample observation, and (3) protargol staining (for details see Macek et al. 1996). For more details of the above approaches and criteria used for grouping ciliates into different taxonomic categories, see Šimek et al. (1995; and references therein). The taxonomy of oligotrichous ciliates is undergoing revision and we based our identifications on the publications of Foissner et al. (1991, 1999), Foissner (1994), and Foissner \& Berger (1996) and detailed references therein.

Field data-Halteria tracer ingestion and food vacuole content. During the examination for FLB uptake, the ciliates with ingested tracers were tentatively identified, which in the case of Halteria was possible using cell size, shape and size of nuclei, and the arrangement of FLB in food vacuoles. Only heterotrophic halteriid species were considered, thus excluding for example the mixotrophic Pelagohalteria viridis. Each individual of unambiguously identified Halteria (the taxon identifications were confirmed in protargolstained impregnations) was measured with an ocular micrometer in a fluorescence microscope, numbers of ingested FLB were counted, and the food vacuole content was also inspected for uptake of natural phytoplankton based on autofluorescence of chlorophyll. Ingested algae or cyanobacteria were measured with an ocular micrometer and recorded as either pico$(<2 \mu \mathrm{m})$ or nano-sized $(>2$ to $<20 \mu \mathrm{m}$ ) phytoplankton prey. Thus each individual ciliate was characterized by its cell volume (calculated by approximation to prolate spheroid), uptake rate of bacteria under in situ temperature, and presence (enumerated and sized) or absence of phytoplankton prey in food vacuoles.

A total of 879 individuals of Halteria from grazing experiments were inspected in both reservoirs at different periods or seasons as specified below. From the 
Římov Reservoir, 585 individuals of Halteria were examined with 235 cells from the epi- and metalimnion of the reservoir during August-September 1993, 125 epilimnetic specimens from October 1994, and 225 epilimnetic individuals from April through October 1997. From the Sau Reservoir, a total of 294 individuals from the epilimnetic populations of Halteria were inspected during 3 periods: 86 cells from July 1996, and 113 and 95 individuals from the longitudinal sampling campaigns in April and July 1997, respectively.

Halteria - calculated doubling time based on picoplanktivory. Potential doubling times were calculated based on the estimated amount of bacterial carbon consumed, and in a 1993 subset of data from the Rímov Reservoir, the amount of carbon consumed as autotrophic picoplankton (APP) as well. The amount of carbon ingested by individual ciliates was calculated from grazing rates multiplied by the amount of organic carbon per food particle (bacteria and/or APP; for details of APP see Šimek et al. 1996). Cell volumes of ciliates and those of their ingested picoplankton prey were transformed to carbon using the following conversion factors (in $\mathrm{fg} \mathrm{C} \mathrm{m}^{-3}$ ): ciliates, 140, recommended for formaldehyde-fixed samples (Putt \& Stoecker 1989); bacteria, 231 and 192 (calculated according to Norland [1993], corresponding to the mean cell volumes of bacteria in both study sites, i.e., 0.062 and $0.105 \mu^{3}$ in the Římov and Sau reservoirs, respectively); and picocyanobacteria, 200 (Weisse 1993). The mean cell volumes of bacteria used were based on 52 (Římov) and 22 (Sau) bacterial size determinations (always $>400$ bacterial cells measured per sample) conducted along with the measurement of uptake rates of Halteria on bacteria. To convert the carbon data into potential doubling times of the ciliates, we used $35 \%$ gross growth efficiency for bacterivorous ciliates (see Šimek et al. 1996, and references therein).

\section{RESULTS}

In most cases, the mean uptake rates were between 6 and 20 FLB per Halteria cell during 5 to 10 min exposure to a tracer concentration that was typically $<10 \%$ of bacterial concentration. The distributions of the uptake data were not significantly different from a normal distribution of prey item per ciliate. Fig. 1 shows 3 examples from dates when the highest number of the ciliate individuals was inspected in samples collected from the same locality. In each example, the data distribution was not significantly different from a normal distribution and, except for the data set from October 1994, it differed significantly from a Poisson distribution (Kolmogorov-Smirnov test, $\mathrm{p}>0.5$ ). Thus, with regard to the typical data distribution, we used the

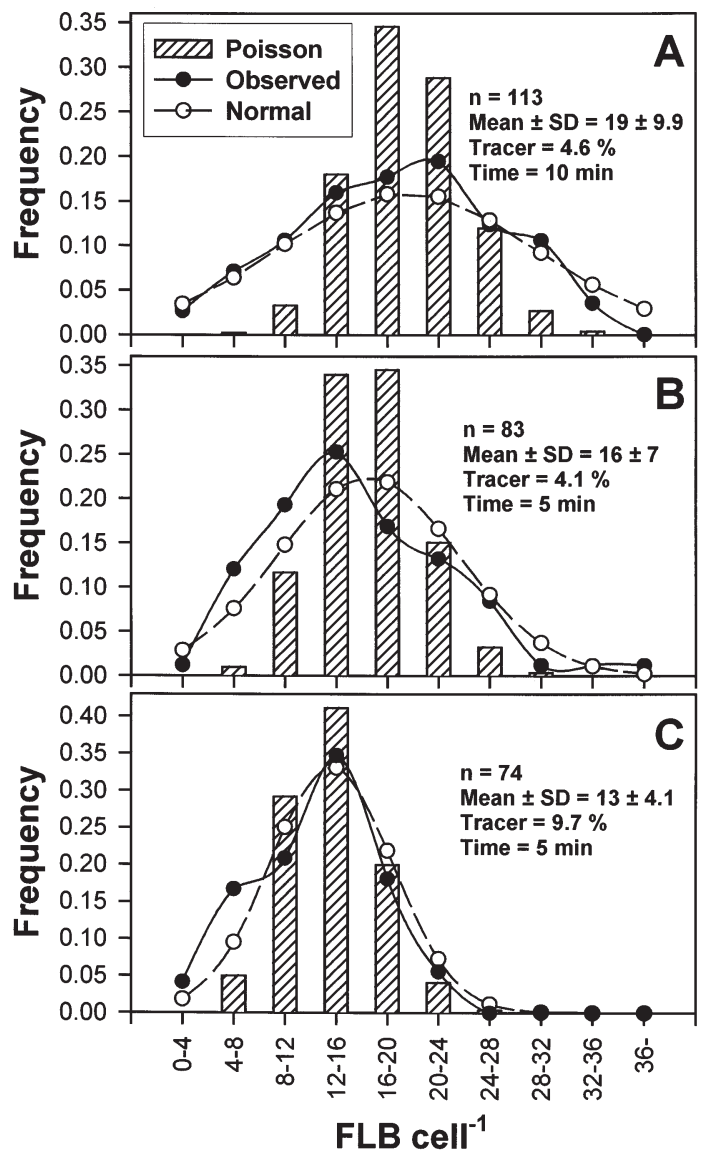

Fig. 1. Three examples of the frequency distribution of FLB uptake data of Halteria spp. representing samples with the highest abundance and number of ciliate individuals inspected. (A,B) The Sau Reservoir, 16 April 1997 and 10 July 1996, water temperature $16^{\circ} \mathrm{C}$ and $23.2^{\circ} \mathrm{C}$, respectively; (C) The Ř́mov Reservoir, 4 October 1994, water temperature $14^{\circ} \mathrm{C}$. Each panel shows the corresponding parameters of mean uptake rate (fluorescently labelled bacteria [FLB] per cell $\pm \mathrm{SD}$ ), number (n) of individuals inspected, tracer amount of FLB added, and time of incubation of the sample

mean uptake rate per ciliate for calculating total ciliate grazing rate.

To illustrate the importance of Halteria, and of total ciliates, as bacterial consumers in the different mesoand eutrophic systems, we present details of 2 data sets (Figs. $2 \& 3$ ) out of the entire database, which is summarized in Fig. 4. Fig. 2 shows the seasonal development of selected microbial parameters in the Rímov Reservoir in 1997. Between April and October, 1 conspicuous peak and 2 less remarkable increases of ciliate abundance occurred, i.e., 102, 45, and 41 ciliates $\mathrm{ml}^{-1}$, in the middle of May, July, and September, respectively. In general, they occurred with or just after peaks of bacterial and HNF abundances, which varied from 2.23 to $6.32 \times 10^{6}$ bacteria $\mathrm{ml}^{-1}$ and 0.44 to $2.92 \times 10^{3} \mathrm{HNF} \mathrm{ml}^{-1}$, respectively (data not shown) over the study period. 
Grazing rates of HNF ranged from 5 to 31 bacteria $\mathrm{HNF}^{-1} \mathrm{~h}^{-1}$ (mean $\pm \mathrm{SD}, 14.4 \pm 6.4$ bacteria $\mathrm{HNF}^{-1} \mathrm{~h}^{-1}$ ), with the lowest values at the cold water period in April. Separately, we enumerated unambiguously identifiable individuals of the group Halteria. Their numbers ranged from $<1 \mathrm{cell} \mathrm{ml}^{-1}$ in early April to $55 \mathrm{cells} \mathrm{ml}^{-1}$ in the middle of May (Fig. 2A) and temporal changes paralleled shifts in total ciliate abundance.

Bacterial production (BP) showed 2 apparent maxima, in the middle of May and in early August (Fig. 2B), i.e., shortly after the spring phytoplankton peak, and coinciding with the summer phytoplankton peak, respectively (data not shown). Minima of BP were observed at the beginning of April (before stratification) and during the transient stage between the clear water phase (with the minimum chlorophyll a concentration of $4 \mathrm{\mu g} \mathrm{l}^{-1}$ in early June) and the onset of the summer phytoplankton peak by the end of June. On average, $58 \%$ of BP was consumed by total protozoa, with slightly more important ciliate bacterivory (32\%) compared to that of HNF ( $26 \%$ of the total BP grazed). On a seasonal basis, however, there were significant differences in absolute and relative values of the bacterial loss rate due to protistan bacterivory. During the late April-early May period and the clear water phase (first half of June), protistan bacterivory was generally low and removed only a small proportion of BP $(<25 \%)$. However, protistan bacterivory almost balanced BP for most of May and the late summer-early fall period.

Grazing of Halteria alone accounted for, on average, $54 \%$ of total ciliate bacterivory; thus, changes in total protozoan grazing rate were tightly correlated with the abundance of Halteria $\left(\mathrm{r}^{2}=0.789, \mathrm{n}=17, \mathrm{p}<0.001\right)$. Fig. 2C clearly documents, except for a few data points, the dominating role of Halteria and of other oligotrichs in ciliate bacterivory. This holds especially true for the June period when only 2 small oligotrichs, Halteria (Fig. 2C) and the closely related mixotrophic Pelagohalteria viridis (data not shown), ingested bacteria, with the latter species shortly dominating ciliate bacterivory. Oligotrichs dominated bacterivory in 14 out of 17 assays. In the remaining 3 samples, the most important group, designated as 'others' (see Fig. 2C), was largely peritrichs, dominated by the genera Vorticella, Epistylis, Carchesium, and by some unidentified species attached to zooplankton (data not shown). Uptake of bacteria by these forms accounted for most of the ciliate bacterivory in the samples from April and October. Bacterivory by scuticociliates, especially of Cyclidium spp., while detectable in about half of the plankton samples (Fig. 2C), was never quantitatively important $(<15 \%)$.

Fig. 3 shows changes in selected microbial parameters in April 1997 along the longitudinal axis of the Sau Reservoir, which is supplied with organically loaded

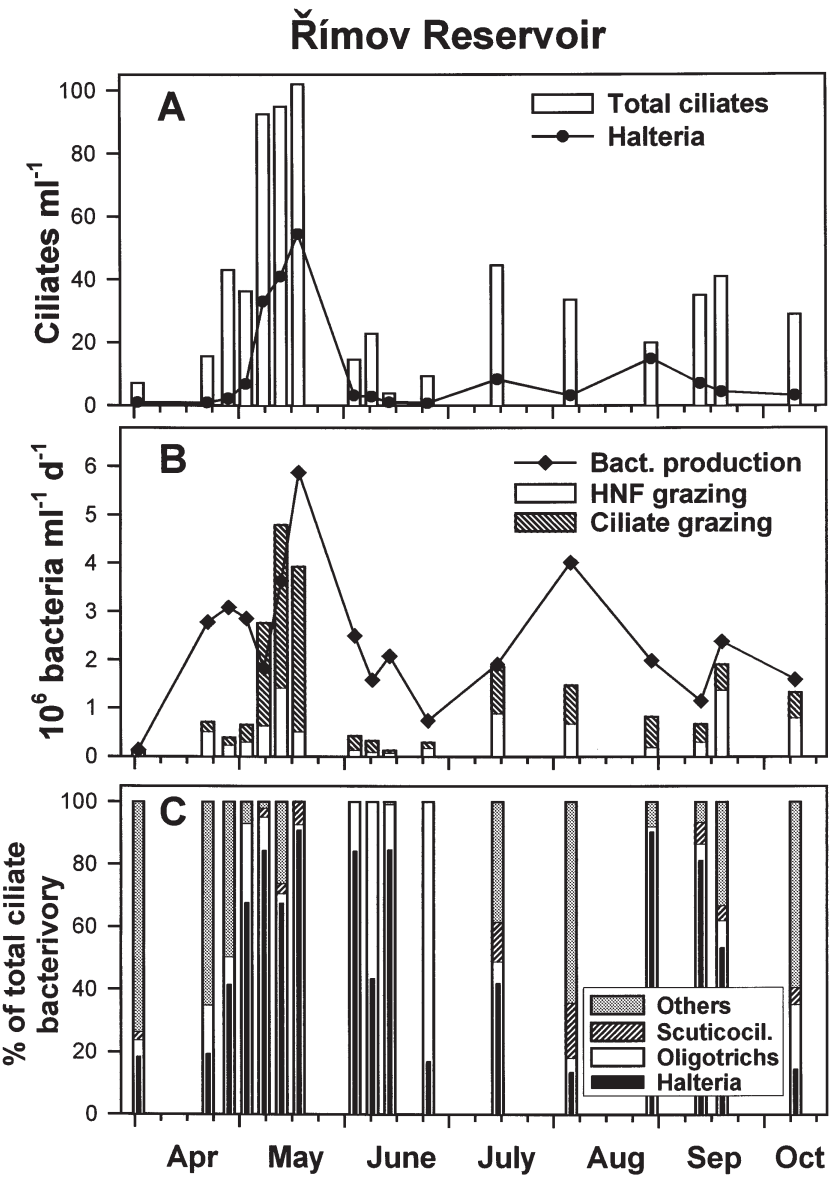

Fig. 2. The Ǩ́mov Reservoir, April to October 1997. (A) Total ciliate abundance and abundance of Halteria, (B) bacterial production and total protistan bacterivory divided into heterotrophic flagellate (HNF) and ciliate grazing, and (C) the role of different ciliate taxa in total ciliate bacterivory. Note that the group 'oligotrichs' represents the aggregated bacterivory of all oligotrichous ciliates compared to the bacterivory of Halteria spp. only, and the group 'others' was dominated by grazing activity of peritrichous ciliates (for details see text)

river water with a high allochthonous bacterial biomass and production (see Fig. 3B). Bacterial densities declined from $16 \times 10^{6}$ cells ml $^{-1}$ at the river to $<5 \times 10^{6}$ cells $\mathrm{ml}^{-1}$ downstream (Stn 1); HNF numbers ranged from $\sim 2$ to $5 \times 10^{3} \mathrm{HNF} \mathrm{ml}^{-1}$, except for a conspicuous

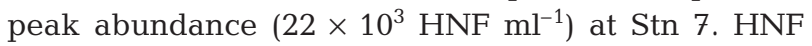
grazing rates ranged from 12 to 67 bacteria $\mathrm{HNF}^{-1} \mathrm{~h}^{-1}$ $\left(\right.$ mean $\pm \mathrm{SD}, 24.1 \pm 17.1$ bacteria $\mathrm{HNF}^{-1} \mathrm{~h}^{-1}$ ), with the highest values at Stn 7 along with a peak of large chrysomonads (see Šimek et al. 1998a). Total ciliate and Halteria numbers showed a similar pattern with minima at the river inflow and close to the reservoir dam (Stn 1) and sharp maxima of 144 and 105 cells $\mathrm{ml}^{-1}$, respectively, at Stn 4 (Fig. 3A).

There was a negligible grazing impact of protists on the extremely high production of the allochthonous 
bacterial populations brought by the river to the reservoir ('river' and Stn 8, Fig. 3B). However, downstream, at Stn 7, there was a distinct HNF peak, corresponding to HNF bacterivory that was roughly double the rate of BP. However, from Stn 6 downstream to Stn 2, ciliates clearly dominated bacterivory. Halteria consumed the bulk of BP at Stns 6, 4, and 3 and slightly less at Stn 2, and contributed about equally with the ciliate group 'others' to total bacterivory at Stn 5 (Fig. 3B,C). Among other oligotrichs ingesting FLB, we observed mainly small strobiliids. The ciliate group 'others' was dominated by bacterivory of the peritrich genera of Vorticella and Epistylis (data not shown). Scuticociliates (i.e., the genera Cyclidium and Uronena) were more
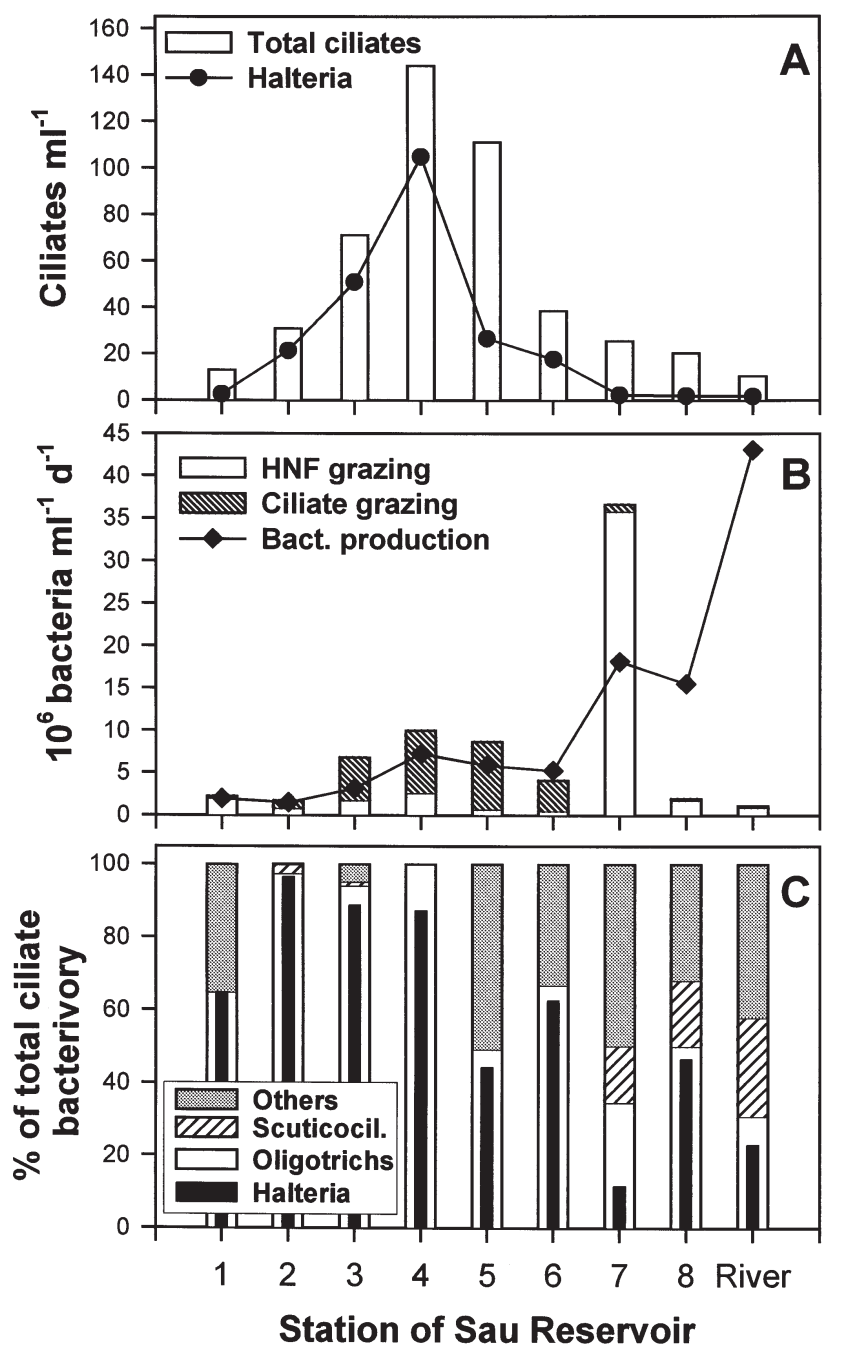

Fig. 3. An example of the longitudinal transects through the Sau reservoir, April 1997. (A) Total ciliate abundance and abundance of Halteria, (B) bacterial production and total protistan bacterivory divided into HNF and ciliate grazing, and (C) the role of different ciliate taxa in total ciliate bacterivory. For other explanations see Fig. 2 important in total ciliate bacterivory in the upper, inflow parts of the reservoir. However, due to their generally low abundance, their contribution to total bacterial loss rate caused by ciliates was small (always $<24 \%$; cf. Fig. 3A,C).

We summarized all our published and unpublished results from both reservoirs where bacterivory of total HNF and ciliates, as well as individual ciliate taxa, were analyzed to illustrate the overall importance of Halteria as a bacterial consumer (Fig. 4). This summary of protistan bacterivory in the epilimnetic waters was based on the average values, representing 52 analyses conducted in the Římov Reservoir: 32 in 1993 (Šimek et al. 1995), 3 in 1994, and 17 in 1997 (see Fig. 2). From the Sau Reservoir we analyzed 22 samples: 4 in 1996 and 18 in 1997 split into two 9-sample subsets from the 2 longitudinal sampling campaigns. On average, HNF and ciliates together consumed a total of 65 and $75 \%$, and Halteria alone 13 and $22 \%$ of total BP in the epilimnion of the Rímov and Sau reservoirs, respectively (Fig. 4). While in the meso-eutrophic Rímov Reservoir HNF populations contributed on average $60 \%$ and cil-
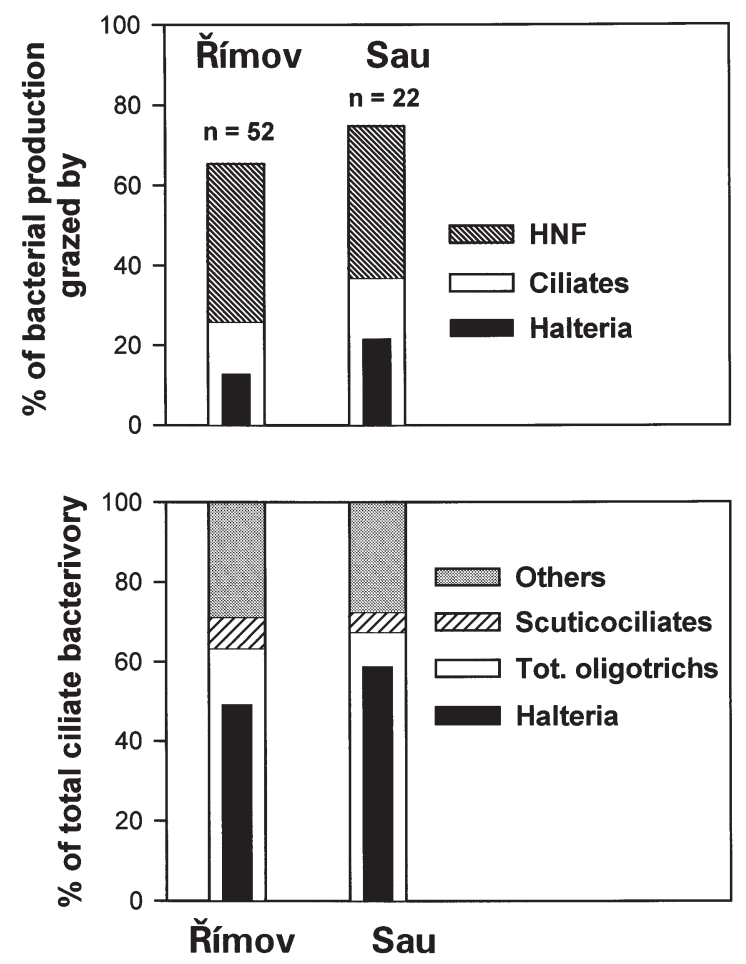

Fig. 4. (A) Overall averages (of $n$ measurements) of the proportions of bacterial production grazed by all protozoans (the full size of the bars), grazed by HNF and ciliates separately, and grazed only by Halteria in the Ŕmov (data from seasons 1993, 1994 and 1997) and Sau reservoirs (data from June 1996 to July 1997). (B) Overall averages of the role of different ciliate taxa in total ciliate bacterivory. For other explanations see Fig. 2 
iates $40 \%$ of the total protistan grazing, in the Sau Reservoir, their contributions to total protistan bacterivory were approximately equal. Plastidic flagellates were not important bacterivores in either reservoir, as they consumed $<1 \%$ of BP (data not shown).

The 4 major groups of ciliates we distinguished showed different, but for the respective group in both systems similar, contributions to the total ciliate bacterivory (Fig. 4). Oligotrichs clearly dominated with 63 and $68 \%$, mainly due to bacterivory of Halteria accounting for 49 and $59 \%$ of the total ciliate bacterivory in the Rímov and Sau reservoirs, respectively. The contributions of scuticociliates were within the range of 5 to $8 \%$, but 'others', mainly peritrich ciliates (Vorticalla, Epistylis, and Carchesium), significantly contributed $(\sim 30 \%)$ to ciliate bacterivory in both reservoirs.

The important role of Halteria in bacterivory was not only a result of the frequent numerical dominance of halteriids in our studies (e.g., Figs. 2A \& 3A), but also of its very high bacterial consumption rates. Table 1 shows mean, median and ranges of values of the ciliate cell volumes, and grazing and clearance rates. Since the parameters of the populations of Halteria from both reservoirs differed remarkably (see Table 1), we treated the data set separately. Mean uptake rates and mean cell volumes $( \pm \mathrm{SD})$ of Halteria were: $1782 \pm 864$ and $3220 \pm 1920$ bacteria cell $^{-1} \mathrm{~h}^{-1}$, and $2497 \pm 1025$ and $1950 \pm 860 \mu^{3}$ in the Římov and Sau reservoirs, respectively (Table 1). We tested if there was a positive correlation between cell volume and grazing rate of the ciliate. There were significant, but rather weak, relationships between cell volume and grazing rate of $\mathrm{Hal}$ teria $\left(\mathrm{r}^{2}=0.086\right.$ and $0.118, \mathrm{n}=585$ and 294, $\mathrm{p}<0.001$, in the Ǩ́mov and Sau reservoirs, respectively). Different water temperatures in the reservoirs could also influence grazing rates of ciliates. To correct the potential effect of this factor, we normalized the grazing data to the mean temperature at both study sites using $Q_{10}=$ 2.5. However, there was no positive effect of this correction on the correlation between the cell volume of Halteria and its grazing rate $\left(\mathrm{r}^{2}=0.053, \mathrm{n}=585, \mathrm{p}<\right.$ 0.001) in the Ŕimov Reservoir. Only the correlation of the data from the Sau Reservoir became slightly closer $\left(\mathrm{r}^{2}=0.162, \mathrm{n}=294, \mathrm{p}<0.001\right)$.

For a rough estimate of doubling times of Halteria based exclusively on carbon from bacteria, the mean cell volumes of ciliates (Table 1) and of ingested bacteria were transformed into carbon units (for details see 'Materials and methods'). Assuming a gross growth efficiency of $35 \%$ and using our data on the mean uptake rates (Table 1), the growth rate of Halteria would be $0.49 \mathrm{~d}^{-1}$ in the Rímov Reservoir and $1.10 \mathrm{~d}^{-1}$ in the Sau Reservoir. During the 1993 study, we measured grazing rates on bacteria and picocyanobacteria in the Římov Reservoir (see Šimek et al. 1995). Estimating the

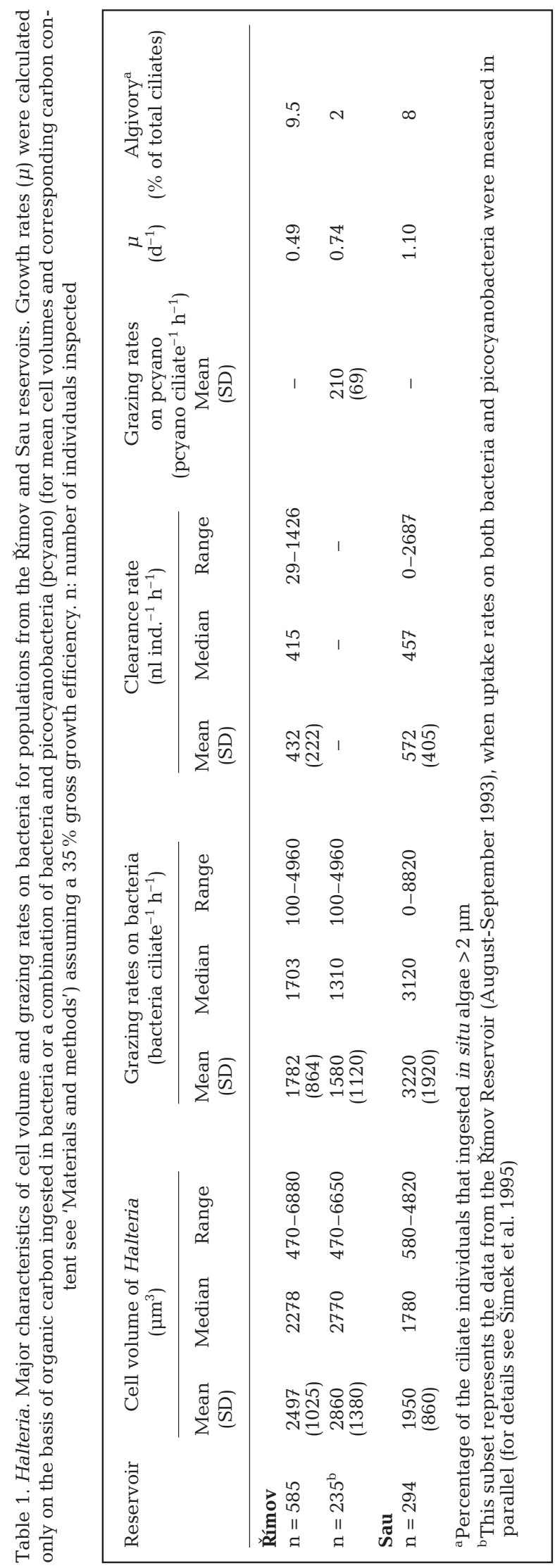


doubling time of the ciliates based on carbon ingested as both heterotrophic bacteria and picocyanobacteria yields a generation time of $0.74 \mathrm{~d}^{-1}$ (Table 1). Our inspection of food vacuole content of Halteria (Table 1) revealed that only a very small percentage of ciliate cells ingested phytoplankton other than picocyanobacteria, on average 9.5 (Římov) and $8 \%$ (Sau). Almost all ingested algal preys ( 0 to 4 cells ciliate ${ }^{-1}$ ) were within a size range of 2 to $4 \mu \mathrm{m}$, and algal prey $>5 \mu \mathrm{m}$ were not found in food vacuoles of the ciliate.

\section{DISCUSSION}

The high protist-induced bacterial mortality in both reservoirs can be associated with a rather moderate top-down control of protistan populations by metazooplankton. A common feature of both systems is that a pronounced grazing impact by cladocerans (mainly Daphnia spp.) is usually limited to a short clear water phase in the Římov and Sau reservoirs. In the Římov Reservoir, there was a sharp decrease in total ciliates, Halteria, and HNF (data not shown) abundance during the clear water phase, June 1997 (Fig. 2). This phenomenon corresponded with marked seasonal maxima of abundance and bacterivory of daphnids and has been previously reported for the reservoir (Šimek et al. 1990) and some lakes (Pace et al. 1990, Jürgens 1994). The clear water phase also yielded a seasonal minimum of the role of protists in consuming BP (Fig. 2). In general, 1997 (Fig. 2) was rather exceptional, as ciliate grazing accounted for, on average, more than $50 \%$ of total protistan bacterivory. In contrast, during 1987 (Šimek et al. 1990) and 1988 (Šimek \& Straškrabová 1992) ciliate grazing exceeded HNF bacterivory only during a late summer-fall period. In general, the increased importance of ciliates in total protistan bacterivory (Fig. 2) was closely linked to seasonal changes in the abundance of Halteria.

In the Sau Reservoir (Fig. 3), there was a clear downstream trend in the abundances and succession of microbial communities, i.e., bacteria-HNF-ciliates, which was perhaps linked to their potential growth rates and changes in water flow regime. The river inflow showed a conspicuous peak in BP and negligible protistan bacterivory corresponding to very low protist abundances (Fig. 3). A few hundred meters downstream a marked HNF population peak occurred. From Stn 6 downstream to Stn 2, HNF, as the major bacterivores, were replaced by ciliates largely due to bacterivory of Halteria (cf. Fig. 3A,C).

Overall, our data indicated 2 important findings from the lower (Římov) towards the higher trophic status (Sau) in the reservoirs: (1) an increasing portion of BP consumed by protists, and (2) an increasing role of cil- iate grazing accounting for 40 and $50 \%$ of the total protistan bacterivory in the Rímov and Sau reservoirs, respectively (Fig. 3). Several possible sources of overand underestimates of the production and grazing data (for details see Sherr et al. 1989) could have influenced these conclusions. Specific details of our modified protocols for the FLB uptake measurements have been discussed in Šimek \& Straškrabová (1992) and Šimek et al. (1995, see also Fig. 1). McManus \& Ocubo (1991) reported 3 major potential sources of error present in such surrogate experiments:

(1) Ingestion is concentration dependent; thus, addition of surrogates may itself increase grazing. To minimize such an error, we kept FLB additions as low as possible within a rather narrow range, i.e., mostly below $15 \%$ (9 to $17 \%$ ) in the case of HNF and below $10 \%(3.7$ to $10 \%)$ in the case of ciliates, with the majority of samples with oligotrichs receiving FLB additions $<5 \%$. Hence, HNF uptake data, rather than the estimates for ciliates, could be more significantly overestimated. (2) A linear approximation of uptake is assumed in short time uptake experiments. Our data showed a near-linear increase of food particles per protozoan cell for both HNF and ciliates (see, e.g., Fig. 2 in Jürgens \& Šimek 2000). (3) As shown for several species of flagellates (McManus \& Ocubo 1991), the distribution of surrogates in grazers does not support the idea of random encounter and ingestion, even for a uniform population of grazers. Thus, data on HNF grazing seem to be prone to a larger statistical error then those for ciliates, since at different tracer exposure times there is a significant and varying proportion of HNF cells with no FLB ingested. It can also partly reflect the fact that HNF represent a mixed community of a largely unknown taxonomic composition, or a community where only a few dominant bacterivorous HNF could be tentatively identified (cf. Šimek et al. 1997). Among typical bacterivorous HNF, we always included 'non-responders' (i.e., those HNF with zero FLB cell ${ }^{-1}$ ) into the calculation of the mean uptake per cell. To minimize the error that can result from such a data distribution, we inspected up to $200 \mathrm{HNF}$ individuals per time point.

On the other hand, a non-normal data distribution does not seem to be inherent in the uptake of the monospecific ciliate populations (e.g., Fig. 1). Due to a very low proportion of ciliates with zero FLB per cell, a generally higher number of FLB per ciliate (as opposed to HNF), and a close match between mean and median values of grazing rate per ciliate (see, e.g., Table 1), the distribution of the uptake data (as FLB per ciliate cell) is not statistically different from a normal distribution (Fig. 1). Our data on ciliate bacterivory could also have been overestimated due to FLB counted in ciliate food vacuoles that were primarily ingested by HNF and 
then secondarily consumed by ciliates. However, considering typical densities and grazing rates of HNF (see 'Results'; Šimek et al. 1995, 1997), clearance rates of Halteria (Table 1; Šimek et al. 1996), and the short incubation times and low FLB tracer amounts used (see 'Material and methods'), this source of error seems to be negligible. For instance, for Halteria we calculated that indirect FLB uptake via HNF would always account for $<5 \%$ of its estimated bacterivory. Thus, we conclude that our FLB approach produced reliable evidence on the role of ciliate bacterivory in the Rímov and Sau reservoirs.

The most important parameter that could bias our estimates of BP is the factor used for converting thymidine incorporation rate to cell production of bacteria. Therefore, we applied our ECF whenever possible. Our values of ECF are close to the theoretical ones, matching the typical range of values reported for freshwater bacteria (Smits \& Riemann 1988).

There was a difference between the Rímov and Sau reservoir populations of Halteria in cell volumes, with larger cells found in the Rímov Reservoir (Table 1). When a maximum shrinkage of individuals of Halteria fixed with Lugol's solution is assumed (30 to 35\%, Wiackowski et al. 1994b), and we use their mean cell volumes reported in Table 1, this would yield a live volume of 3246 to 3371 and 2535 to $2633 \mu^{3}$ for the Ř́mov and Sau reservoirs, respectively. The calculated mean live volume of Halteria in the Rímov Reservoir is very close to that of well-fed individuals of the ciliates from batch cultures with algae $\left(3754 \pm 890 \mu^{3}\right.$, Jürgens \& Šimek 2000). The individuals from the Sau Reservoir were much smaller, but without a large difference in clearance rates compared to the populations from the Rímov Reservoir (Table 1). Thus, with a similar clearance rate these Halteria populations in the Sau Reservoir could: (1) meet their carbon requirements much faster, (2) thus also realize shorter doubling times than in the Rímov Reservoir, and (3) compete more efficiently for bacterial food sources, with a higher volume-specific clearance rate in the Sau Reservoir.

We also tried to determine if individual ciliate uptake was positively correlated with an individual cell volume of the ciliate. Assuming that the larger individuals should have higher grazing rates, the changes in the cell volume of Halteria would explain only between 9\% (Ř́mov) and 12\% (Sau) of the variability in our uptake data. Normalizing for potential temperature effects $\left(Q_{10}=2.5\right)$ improved the correlation from the Sau Reservoir only slightly, explaining $\sim 16 \%$ of the uptake data measurements. A similar weak relationship between cell volume and uptake rates on bacteria was also found for a natural lake population of Cyclidium sp. (Šimek et al. 1998b). There are probably other factors, besides temperature and cell volume, which affect the feeding rate, such as physiological state, cell cycle (the largest, dividing ciliates had usually very low uptake rates), food availability and food quality (see also Legner 1975, Jürgens \& Šimek 2000). There is also the possibility that the pooled group Halteria indeed did not comprise only the most frequently identified $H$. grandinella, but also the closely related species $H$. bifurcata and Pelagohalteria cirrifera (Foissner at el. 1999), or a species complex with different subspecies of slightly deviating morphology and ecological behavior.

Laboratory experiments showed that the typical food items, i.e., hetero- and autotrophic picoplankton and 3 to $4 \mu \mathrm{m}$ sized Chlorella sp. were efficiently ingested and then digested by Halteria sp. within $\sim 2.5$ to $4 \mathrm{~h}$ (Jürgens \& Šimek 2000). Both the laboratory and field experiments indicate that Halteria feeds on different trophic levels (hetero- and autotrophic picoplankton and small HNF). This likely species complex has a large prey size spectrum compared to a strictly bacterivorous species, though some authors consider, e.g., H. grandinella as primarily bacterivorous (e.g., Taylor 1978). By virtue of its omnivory and very high clearance rates on bacteria, Halteria can compete with HNF by feeding on the same food sources, moreover the ciliates can also prey on HNF (Cleven 1996, Jürgens et al. 1996).

The high uptake rates of bacteria and picoalgae by Halteria in the reservoirs imply that these ciliates can meet most of their carbon requirements through picoplanktivory (Table 1). The existing evidence that Halteria can subsist on bacteria alone is contradictory: Skogstad et al. (1987) and Jürgens \& Šimek (2000) were not successful in cultivating members of this species complex on bacteria alone, whereas Taylor (1978) reared $H$. grandinella in batch cultures exclusively on a purely bacterial culture of Aerobacter aerogenes. Our analyses of food vacuole content of Halteria from both reservoirs (Table 1) indicate a rather limited importance of algae in the diet of natural populations of the ciliates. Small algae (2 to $5 \mu \mathrm{m}$ ) were usually observed at low abundances and not more than $9 \%$ of pelagic Halteria individuals were found with ingested algae ( 2 to $4 \mu \mathrm{m}$ large cells). Thus, our data suggest that picoplankton was the major source of organic carbon for the ciliate in our systems.

For instance, multiplying the mean cell volumes of bacteria by the grazing rates of Halteria on bacteria in the Rímov $\left(0.062 \mu \mathrm{m}^{3}, 1782\right.$ cells ind. $\left.{ }^{-1} \mathrm{~h}^{-1}\right)$ and Sau reservoirs $\left(0.105 \mu^{3}, 3220\right.$ cells ind $\left.{ }^{-1} \mathrm{~h}^{-1}\right)$ yields a total of 111 and $338 \mu^{3}$ of bacterial volume biomass ingested hourly, respectively. In comparison, even in the rare case of a ciliate cell with 4 ingested algae with a maximum diameter of $4 \mu \mathrm{m}$, this would yield only about $100 \mu^{3}$ of algal volume biomass ingested. Fur- 
ther, experimental data showed (Dolan \& Šimek 1997, Jürgens \& Šimek 2000) that for the full digestion of algal cells, involving also the complete disappearance of their chlorophyll autofluorescence, oligotrichs need at least 2 to $3 \mathrm{~h}$. Hence, the algae distinguished according to their autofluorescence within ciliate food vacuoles represent algivory over 2 to $3 \mathrm{~h}$ prior to fixing the ciliates. Thus, among the food items distinguishable within ciliate food vacuoles, bacteria were quantitatively the most important food source.

This is also indicated by our estimates of Halteria growth rates, assuming exclusive picoplanktivory, i.e., 0.75 and $1.1 \mathrm{~d}^{-1}$ for the Ř́mov and Sau reservoirs, respectively (Table 1). To compare the latter estimates with those independently derived from changes in the ciliate abundance with time, we summarized available published and unpublished data on the maximum net growth rate of the ciliate determined in predatorremoval experiments with water samples pre-screened through meshes of different sizes (for details see Table 2). Our estimates, derived from $20 \mu \mathrm{m}$ treatments incubated in the Rímov Reservoir in dialysis bags during 1997 (see Šimek et al. 1999), matched quite well those listed in Table 1. It provided additional support to our finding that picoplanktivory significantly contributed to the diet of the ciliate. The highest growth rate estimates of Halteria (Table 2) were reported by Jürgens et al. (1999) from a hypertrophic Danish lake during a bloom of pico- and nanoalgae (including Chlorella spp.), suggesting that phytoplankton can be an important food resource for Halteria in some lakes. On the other hand, almost the same maximum net growth rate $\left(1.73 \mathrm{~d}^{-1}\right)$ was also found when Halteria sp., reported as $H$. grandinella, was reared on a pure bacterial culture (Taylor 1978). Legner (1975) reported a maximum growth rate as high as $3.1 \mathrm{~d}^{-1}$ for $H$. grandinella growing in organically enriched sam- ples from 2 reservoirs. Hence, the above references and Table 2 clearly document an apparent food flexibility of the small halteriids and their high growth potential under food-satiated conditions. Other potential food items, falling into the size range of particles ingested by the omnivorous halteriids (Jürgens \& Šimek 2000) are HNF and small detritus particles. They represent potentially important carbon sources, but we cannot distinguish them within ciliate food vacuoles.

To document also the numerical importance of small halteriids, mostly reported as Halteria grandinella in different lakes and reservoirs, we collected the available published and unpublished data (Table 3). Halteria has been found worldwide across the trophic spectrum of lakes (see also Table 4.1 in Laybourn-Parry 1992). This suggests that Halteria might be an important bacterivore in a broad variety of temperate aquatic systems (Stabell 1996, Figs. 2 to 4), becoming more dominant in eutrophic lakes. It is reported in abundances ranging from $<1$ to 389 ind. $\mathrm{ml}^{-1}$ along the trophic gradient from oligo- to hypertrophy. Halteria has uptake and clearance rates on bacteria (Table 1) about 2 orders of magnitude higher than the typical in situ uptake rates of freshwater HNF, 10 to 25 bacteria ind. ${ }^{-1} \mathrm{~h}^{-1}$ (e.g., Sanders et al. 1989, Vaqué et al. 1994, Šimek et al. 1997). Since abundances of Halteria and small oligotrichs increase towards eutrophic and hypertrophic systems (cf. Figs. 2 \& 3, Table 3; Nakano et al. 1998, Jürgens et al. 1999), it is not surprising that total ciliate bacterivory becomes as important as HNF bacterivory (Fig. 4). Regarding the role of ciliates as bacterivores, 2 important points should be stressed:

(1) While a general trend towards an increasing role of bacterivorous ciliates with increasing trophic status was suggested by Beaver \& Crisman (1989), HNF have been ascribed the role as the most important bacteri-

Table 2. Literature and unpublished data on in situ measured maximum net growth rate of Halteria in predator-removal experiments. Numbers of ciliate individuals represent a range of values between the initiation and end of the experiment

\begin{tabular}{|c|c|c|c|c|c|}
\hline Lake/reservoir & Country & Trophic status & No. $\mathrm{ml}^{-1}$ & $\begin{array}{l}\text { Max. net growth } \\
\text { rate }\left(\mathrm{d}^{-1}\right)\end{array}$ & $\begin{array}{l}\text { Source/experimental } \\
\text { treatment }\end{array}$ \\
\hline Lake Søbygård & Denmark & $\begin{array}{l}\text { Hypertrophic } \\
\text { shallow lake }\end{array}$ & $<10-380$ & $1.64-1.90$ & $\begin{array}{l}\text { Jürgens et al. (1999)/ } \\
10 \text { and } 50 \mu \mathrm{m} \text { screened samples }\end{array}$ \\
\hline Rixdorfer Teich & Germany & Eutrophic pond & $0.1-21$ & $1.30-1.38$ & Langenheder \& Jürgens (unpubl.) \\
\hline Hasselburger Teich & Germany & Eutrophic pond & $0.5-19$ & $0.82-1.20$ & $\begin{array}{l}\text { Langenheder \& Jürgens (unpubl.)/ } \\
200 \mu \mathrm{m} \text { screened samples }\end{array}$ \\
\hline Heiligensee & Germany & Eutrophic & $<1-10$ & $1.25-1.40$ & $\begin{array}{l}\text { Skibbe (1998) } \\
60 \mu \mathrm{m} \text { screened samples }\end{array}$ \\
\hline Rímov Reservoir, 1993 & Czech Republic & Meso-eutrophic & $1-10$ & 0.8 & $\begin{array}{l}\text { Macek et al. (1996)/ } \\
100 \mu \mathrm{m} \text { screened samples }\end{array}$ \\
\hline Římov Reservoir, 1997 & Czech Republic & Meso-eutrophic & $2-14$ & $0.75-1.05$ & $\begin{array}{l}\text { Simek et al. }(1999)^{\mathrm{a}} \\
20 \mu \mathrm{m} \text { screened samples }\end{array}$ \\
\hline
\end{tabular}


Table 3. Literature values of densities of Halteria, mostly reported as $H$. grandinella, in waters of different trophic status, including unpublished data from several studies

\begin{tabular}{|c|c|c|c|c|}
\hline Lake/reservoir/pond & Country & Trophic status & No. $\mathrm{ml}^{-1}$ & Source \\
\hline Furuike Pond & Japan & Hypertrophic & $25-389$ & Nakano et al. $(1998)^{a}$ \\
\hline Lake Stigsholm & Denmark & Hypertrophic & $15-104$ & Jürgens \& Jeppesen (1998)a \\
\hline Lake Søbygård & Denmark & Hypertrophic & $3-99$ & Jürgens et al. (1999) \\
\hline Pries Pot & UK & Hypertrophic & $10-61$ & Finlay et al. (1988) \\
\hline Pries Pot & UK & Hypertrophic & $1-9$ & Berninger et al. $(1993)^{a}$ \\
\hline Lake Heiligensee & Germany & Hypertrophic & $<1-10$ & Skibbe (1998) \\
\hline Poppelsdorfer Weihers Pond & Germany & Eutrophic & $10-289$ & Wilbert (1969) \\
\hline Two ponds & Canada, Ontario & Eutrophic & $\sim 100$ & Archbold $(1983)^{\mathrm{a}}$ \\
\hline Stagno di Favale Pond & Italy & Eutrophic & $1-40$ & Madoni (1991) \\
\hline $\begin{array}{l}\text { Sau Reservoir, } \\
\text { lacustrine part, } 1997\end{array}$ & Spain & Eutrophic & $7-105$ & This study \\
\hline $\begin{array}{l}\text { Sau Reservoir, } \\
\text { lacustrine part, } 1998\end{array}$ & Spain & Eutrophic & $4-58$ & Comerma (unpubl. data) \\
\hline Lake Oglethorpe & USA & Eutrophic & $0-5$ & Sanders et al. $(1989)^{\mathrm{a}}$ \\
\hline Lake Erie, coastal sites & USA & Eutrophic & $2-30$ & Hwang \& Heath (1997b) \\
\hline Rúmov Reservoir, 1993 & Czech Republic & Meso-eutrophic & $1-10$ & Šimek et al. (1995) \\
\hline Rúmov Reservoir, 1997 & Czech Republic & Meso-eutrophic & $2-14$ & Šimek et al. (1999) ${ }^{\mathrm{a}}$ \\
\hline Rúmov Reservoir, 1997 & Czech Republic & Meso-eutrophic & $1-55$ & This study \\
\hline Rúmov Reservoir, 1999 & Czech Republic & Meso-eutrophic & $1-63$ & Jezbera \& Šimek (unpubl. data) \\
\hline Neusiedler See & Austria & Mesotrophic & $0-7$ & Schönberger (1994) \\
\hline Ruster Poschen Pond & Austria & Mesotrophic & $1-27$ & Schönberger (1994) \\
\hline Lake Erie, offshore sites & USA & Meso-oligotrophic & $1-6$ & Hwang \& Heath (1997b) \\
\hline Traunsee & Austria & Oligotrophic & $0-2.2$ & Sonntag (unpubl. data) \\
\hline Loch Ness & UK & Oligotrophic & $0.1-0.2$ & Laybourn-Parry et al. (1994) \\
\hline
\end{tabular}

vores (e.g., Fenchel 1982, Sanders et al. 1989, Berninger et al. 1991), independent of the trophic state of aquatic systems. The presumed importance of HNF is mainly due their ability to exploit and grow on low in situ bacterial abundances (see also Jürgens 1992). However, this argument does not apply to systems characterized by relatively high bacterial concentrations. Thus, while we still have little information about ciliate bacterivory in eutrophic and hypertrophic lakes, data from the Sau Reservoir (Figs. 3 \& 4; Comerma et al. in press) and a hypertrophic pond in Japan (Nakano et al. 1998) indicate that ciliate bacterivory can exceed that of HNF.

(2) Restricted sets of ciliate types are important pelagic bacterivores. When reviewing data on ciliate bacterivory, there is a close concordance between our results (Fig. 4) and literature data, which enables a certain level of generalization. Based on a set of 100 taxonomic analyses of ciliate bacterivory in 21 systems, i.e., 17 Norwegian lakes of different trophic status (only once sampled, Stabell 1996), 4 samples from coastal and 4 samples from offshore sites of Lake Erie (Hwang \& Heath 1997a), 1 seasonal study on Lake Oglethorpe (Sanders et al. 1989), and 2 seasonally studied reservoirs (52 and 22 samples from the Rímov and Sau reservoirs, respectively), we can conclude that only 3 groups are important pelagic ciliate bacterivores.
These groups with the typical representative genera, in order of their overall decreasing importance as bacterivores, are: (1) small oligotrichs (Halteria, Pelagohalteria, Strobilidium, Strombidium) (2) peritrichs (Vorticella, Epistylis, Carchesium), and (3) scuticociliates (Cyclidium and less frequently Uronema spp.).

Beaver \& Crisman (1989) reviewed an extensive data set characterizing ciliate dynamics in subtropical Florida lakes and suggested that there was an increasing role of scuticociliate bacterivory with increasing trophic status. The situation might be different in temperate lakes. In none of 17 Norwegian lakes (Stabell 1996), nor in the reservoir data presented here (Figs. 2 to 4 ), did mean values of scuticociliate grazing exceed $17 \%$; they were usually below $10 \%$ of total ciliate bacterivory. Two exceptions to this pattern, where bacterivory of Cyclidium spp. clearly dominated, were reported from rather extreme ecosystems, a hypertrophic Japanese lake (Nakano et al. 1998) and a naturally acidic, mesotrophic lake in Germany (Šimek et al. 1998b). Another deviation from the prevalence of bacterivory by oligotrichs has been documented when peritrichs, attached to colonies of cyanophytes (Stabell 1996), large diatoms (Carrias et al. 1996), or to carapaces of large crustacean zooplankton (Kankaala \& Eloranta 1987), are abundant. The vulnerability of the attached peritrichs to metazoan predation is probably 
strongly reduced, compared to small free-living ciliates. Thus, high abundance of metazooplankton can result in dominance of bacterivory by peritrichous ciliates.

It is somewhat unclear whether the jumping response of Halteria sp., reported as H. grandinella (e.g., Tamar 1979, Gilbert 1994), is an effective escape behavior in response to all metazoan predators. Results of recent laboratory (e.g., Gilbert 1994, Jack \& Gilbert 1997 ) and field studies (Havens \& Beaver 1997, Jürgens et al. 1999) imply that the jumping response of Halteria is probably an effective escape reaction against predation by rotifers but not so much against Daphnia spp. or Cyclops spp. (Gilbert 1994, Jack \& Gilbert 1997, Jürgens et al. 1999). Zooplankton communities in both reservoirs were only briefly dominated by Daphnia spp. (Šimek et al. 1990), or possibly by Cyclops spp. Thus, the escape response and the high growth rate of Halteria (e.g., Legner 1975, Taylor 1978, Jürgens et al. 1999; Table 2) can explain why the ciliate communities dominated by $H$. cf. grandinella co-existed with abundant rotifer populations for most of the time in these systems (Šimek et al. 1995, Armengol et al. 1999).

We suggest that there are 4 important reasons behind the exceptional position of Halteria, most frequently identified as $H$. grandinella, in planktonic food webs: (1) high uptake and clearance rates on picoplankton-sized particles, (2) omnivory with an efficient uptake of a large prey size spectrum ( 0.4 to $5 \mu \mathrm{m})$ which covers autotrophic and heterotrophic pico- and nanoplankton and detritus (Jürgens \& Šimek 2000), (3) very high growth rate and abundances in situ (Tables $2 \& 3$ ), and (4) lower vulnerability as prey for metazooplankton than other common ciliate species. Concerning the former 2 points, Halteria showed both the highest uptake and clearance rates on auto- or heterotrophic picoplankton among all in situ studied oligotrichs (Šimek et al. 1996, Stabell 1996; Table 1). Another ecologically important aspect is the very high volume-specific clearance rates of this species measured on bacterial prey, from 0.5 (Stabell 1996) to $1.6 \times$ $10^{5}$ cell volumes $\mathrm{h}^{-1}$ (Šimek et al. 1995). They indicate the ability of Halteria to compete efficiently for the picoplankton food resources with some typical bacterivorous HNF (cf. Fenchel 1986).

We conclude that most of the pelagic ciliates that are efficient bacterial grazers are not bacterivorous in the strict sense, since autotrophic picoplankton and small algae also significantly contribute to their diet (Skogstad et al. 1987, Šimek et al. 1996, Jürgens \& Šimek 2000; Table 1). Thus, we suggest revising the concept of pelagic ciliate bacterivory suggested by Fenchel (1980), since recent data have shown that not specialized bacterivorous ciliates, but small, omnivorous oligotrichs are the major ciliate bacterivores in meso- and eutrophic waters (Šimek et al. 1995, 1996, Stabell 1996, Hwang \& Heath 1997a, Thouvenot et al. 1999; Figs. 1 to 4). Thus, corresponding to the latter, the term 'bacterivorous ciliates' should be used rather for the ciliates that have bacteria not necessarily as an exclusive, but as a major food source. Halteria seems to be the most important taxon within that ecological group which frequently dominates in meso- and eutrophic plankton. Given its strong grazing impact on a wide prey spectrum within the pico- and nanoplankton including small HNF, Halteria might occupy a specific structuring role for the microbial food web in meso- to eutrophic systems.

Acknowledgements. This study was supported by the Grant Agency of the Czech Republic (GA CR) research grants 206/ 99/0028, and 206/96/0012 awarded to K.S., by the GA CR research grant 206/98/0727, by an Academy of Sciences of the Czech Republic (AS CR) grant 'Biodiversity' no. 21/96/K, by an AS CR instrument grant 'Microanalysis of microbial communities' - program 1036, P 1011802, by the Max Planck Society, and by the Aigues Ter-Llobregat Company supporting the study conducted on the Sau Reservoir. We wish to thank John Dolan and Nick Crosbie for correcting the English of the manuscript, Helga Müller and 4 anonymous reviewers for valuable comments on earlier versions of the manuscript, Wilhelm Foissner and Miroslav Macek for help in identifying several species of ciliates, and Robert Sanders, Ulrike Berninger, Betina Sonntag, Oliver Skibbe, and Shin-Ichi Nakano for supplying unpublished data on the abundance of Halteria grandinella in various freshwater systems.

\section{LITERATURE CITED}

Archbold J (1983) Optimal foraging and comparative predator-prey interactions in two species of Dileptus (Protozoa: Ciliophora). PhD thesis, University of Toronto

Armengol J, Garcia JC, Comerma M, Romero M, Dolz J, Roura M, Han BH, Vidal A, Šimek K (1999) Longitudinal processes in canyon type reservoirs: the case of Sau (N.E. Spain). In: Tundisi JG, Straškraba M (eds) Theoretical reservoir ecology and its applications. International Institute of Ecology, Brazilian Academy of Sciences and Backhuys Publishers, Leiden, p 313-345

Beaver JR, Crisman TL (1989) The role of ciliated protozoa in pelagic freshwater ecosystems. Microb Ecol 17:111-136

Berninger U, Finlay BJ, Kuuppo-Leinikki P (1991) Protozoan control of bacterial abundances in freshwaters. Limnol Oceanogr 36:139-147

Berninger U, Wickham, SA, Finlay BJ (1993) Trophic coupling within the microbial food web: a study with fine temporal resolution in a freshwater ecosystem. Freshw Biol 30: 419-432

Carrias JF, Amblard C, Bourdier G (1996) Protistan bacterivory in an oligomesotrophic lake: importance of attached ciliates and flagellates. Microb Ecol 31:249-268

Carrias JF, Amblard C, Bourdier G (1998) Seasonal dynamics and vertical distribution of planktonic ciliates and their relationship to microbial food resources in the oligomesotrophic Lake Pavin. Arch Hydrobiol 143:227-255

Cleven EJ (1996) Indirectly fluorescently labelled flagellates 
(IFLF): a tool to estimate the predation on free-living heterotrophic flagellates. J Plankton Res 18:429-442

Comerma M, Garcia JC, Armengol J, Romero M, Šimek K (in press) Microbial food web structure throughout a gradient of heterotrophy-autotrophy in a canyon shaped eutrophic reservoir. Int Rev Hydrobiol

Dolan JD, Šimek K (1997) Processing of ingested matter in Strombidium sulcatum, a marine ciliate (Oligotrichida). Limnol Oceanogr 42:393-397

Fenchel T (1980) Suspension feeding in ciliated protozoa: Feeding rates and their ecological significance. Microb Ecol 6:13-25

Fenchel T (1982) Ecology of heterotrophic nanoflagellates. VI. Quantitative occurrence and importance as bacterial consumers. Mar Ecol Prog Ser 9:35-42

Fenchel T (1986) Protozoan filter feeding. Prog Protistol 1: 65-113

Fenchel T, Kristensen LD, Rasmussen L (1990) Water column anoxia: vertical zonation of planktonic protozoa. Mar Ecol Prog Ser 62:1-10

Finlay BJ, Clarke KJ, Cowling AJ, Hindle RM, Rogerson A, Berninger UG (1988) On the abundance and distribution of protozoa and their food in a productive freshwater pond. Eur J Protistol 23:205-217

Foissner W (1994) Progress in taxonomy of planktonic freshwater ciliates. Mar Microb Food Webs 8:9-35

Foissner W, Berger H (1996) A user-friendly guide to the ciliates (Protozoa, Ciliophora) commonly used by hydrobiologists as bioindicators in rivers, lakes, and waste water, with notes on their ecology. Freshw Biol 35:375-482

Foissner W, Blatterer H, Berger H, Kohmann F (1991) Taxonomische und ökologische Revision der Ciliaten des Saprobiensystems - Band I. Cyrtophorida, Oligotrichida, Hypotrichia, Colpodea. Informationsberichte des Bayerischen Landesamtes für Wasserwirtschaft, Heft 1/91, Bavarian State Office for Water Management, Munich

Foissner W, Berger H, Schaumburg J (1999) Identification and ecology of limnetic plankton ciliates. Informationsberichte des Bayerischen Landesamtes für Wasserwirtschaft, Heft 3/99, Bavarian State Office for Water Management, Munich

Gilbert JJ (1994) Jumping behaviour in the oligotrich ciliates Strobilidium velox and Halteria grandinella, and its significance as a defense against rotifer predators. Microb Ecol 27:189-200

Güde H (1986) Loss processes influencing growth of planktonic bacterial populations in Lake Constance. J Plankton Res 8:795-810

Havens KE, Beaver JR (1997) Consumer vs. resource control of ciliate protozoa in a copepod-dominated subtropical lake. Arch Hydrobiol 140:491-511

Hwang SJ, Heath RT (1997a) Bacterial productivity and protistan bacterivory in coastal and offshore communities of Lake Erie. Can J Fish Aquat Sci 54:788-799

Hwang SJ, Heath RT (1997b) The distribution of protozoa across a trophic gradient, factors controlling their abundance and importance in the plankton food web. J Plankton Res 19:491-518

Jack JD, Gilbert JJ (1997) Effects of metazoan predators on ciliates in freshwater plankton communities. J Eukaryot Microbiol 44:194-199

Jürgens K (1992) Is there plenty of food for bacterivorous flagellates in eutrophic waters? Arch Hydrobiol Beih Ergebn Limnol 37:195-205

Jürgens K (1994) Impact of Daphnia on planktonic microbial food webs - a review. Mar Microb Food Webs 8:295-324

Jürgens K, Jeppesen E (1998) Cascading effects on microbial food web structure in a dense macrophyte bed. In: Jeppesen E, Søndergaard M, Christoffersen K (eds) The structuring role of submerged macrophytes in lakes. SpringerVerlag, New York, p 262-273

Jürgens K, Šimek K (2000) Functional response and particle size selection of Halteria cf. grandinella, a common freshwater, oligotrichous ciliate. Halteria grandinella Aquat Microb Ecol 22:57-68

Jürgens K, Wickham SA, Rothhaupt KO, Santer B (1996) Feeding rates of macro- and microzooplankton on heterotrophic nanoflagellates. Limnol Oceanogr 42: 1833-1839

Jürgens K, Skibbe O, Jeppesen E (1999) Impact of metazooplankton on the composition and population dynamics of planktonic ciliates in a shallow, hypertrophic lake. Aquat Microb Ecol 17:61-75

Kankaala P, Eloranta P (1987) Epizooic ciliates (Vorticella sp.) compete for food with their host Daphnia longispina in a small polyhumic lake. Oecologia 73:203-206

Laybourn-Parry J (1992) Protozoan plankton ecology. Chapman and Hall, London

Laybourn-Parry J, Walton M, Young J, Jones RI, Shine A (1994) Protozooplankton and bacterioplankton in a large oligotrophic lake - Loch Ness, Scotland. J Plankton Res 16:1655-1670

Legner M (1975) Concentration of organic substances in water as a factor controlling the occurrence of some ciliate species. Int Rev Ges Hydrobiol 60:639-654

Macek M, Šimek K, Pernthaler J, Vyhnálek V, Psenner R (1996) Growth rates of dominant planktonic ciliates in two freshwater bodies of different trophic degree. J Plankton Res 18:463-481.

Madoni P (1991) Community structure and distribution of ciliated protozoa in a freshwater pond covered by Lemna minor. Boll Zool 58:273-280

McManus GB, Okubo A (1991) On the use of surrogate food particles to measure protistan ingestion. Limnol Oceanogr 36:613-617

Müller H (1989) The relative importance of different ciliate taxa in the pelagic food web of Lake Constance. Microb Ecol 18:261-274

Nakano S, Ishii N, Manage PM, Kawabata Z (1998) Trophic roles of heterotrophic nanoflagellates and ciliates among planktonic organisms in a hypereutrophic pond. Aquat Microb Ecol 16:153-161

Norland S (1993) The relationship between biomass and volume of bacteria. In: Kemp PF, Sherr BF, Sherr EB, Cole JJ (eds) Handbook of methods in aquatic microbial ecology. Lewis Publishers, Boca Raton, p 303-308

Pace ML, McManus GB, Findlay SEG (1990) Planktonic community structure determines the fate of bacterial production in a temperate lake. Limnol Oceanogr 35:795-808

Posch T, Pernthaler J, Alfreider A, Psenner R (1997) Cell-specific respiratory activity of aquatic bacteria studied with the tetrazolium reduction method, cyto-clear slides, and image analysis. Appl Environ Microbiol 63:867-873

Putt M, Stoecker DK (1989) An experimentally determined carbon: volume ration for marine 'oligotrichous' ciliates from estuarine and coastal waters. Limnol Oceanogr 34: 1097-1103

Riemann B, Søndergaard M (1986) Carbon dynamics in eutrophic, temperate lakes. Elsevier, New York

Sanders RW, Porter KG, Bennet SJ, DeBiase AE (1989) Seasonal patterns of bacterivory by flagellates, ciliates, rotifers, and cladocerans in freshwater planktonic community. Limnol Oceanogr 34:673-687

Schönberger M (1994) Planktonic ciliates of Neusiedler See (Austria/Hungary) - a comparison between the turbid 
open lake and a reedless brown-water pond. Mar Microb Food Webs 8:251-263

Sherr BF, Sherr EB, Pedrós-Álio C (1989) Simultaneous measurement of bacterioplankton production and protozoan bacterivory in estuarine water. Mar Ecol Prog Ser 54: 209-219

Sherr EB, Sherr BF (1987) High rates of consumption of bacteria by pelagic ciliates. Nature 325:710-711

Sherr EB, Sherr BF (1993) Protistan grazing rates via uptake of fluorescently labeled prey. In: Kemp PF, Sherr BF, Sherr EB, Cole JJ (eds) Handbook of methods in aquatic microbial ecology. Lewis Publishers, Boca Raton, p 695-701

Šimek K, Straškrabová V (1992) Bacterioplankton production and protozoan bacterivory in a mesotrophic reservoir. J Plankton Res 14:773-787

Šimek K, Macek M, Sed'a J, Vyhnálek V (1990) Possible food chain relationships between bacterioplankton, protozoans, and cladocerans in a reservoir. Int Rev Ges Hydrobiol 75:583-596

Šimek K, Bobková J, Macek M, Nedoma J, Psenner R (1995) Ciliate grazing on picoplankton in a eutrophic reservoir during the summer phytoplankton maximum: a study at the species and community level. Limnol Oceanogr 40: 1077-1090

Šimek K, Macek M, Pernthaler J, Psenner R, Straškrabová V (1996) Can freshwater planktonic ciliates survive on a diet of picoplankton? J Plankton Res 18:597-613

Šimek K, Hartman P, Nedoma J, Pernthaler J, Vrba J, Springmann D, Psenner R (1997) Community structure, picoplankton grazing and zooplankton control of heterotrophic nanoflagellates in a eutrophic reservoir during the summer phytoplankton maximum. Aquat Microb Ecol 12: 49-63

Šimek K, Armengol J, Comerma M, Garcia JC, Chrzanowski TH, Macek M, Nedoma J, Straškrabová V (1998a) Characteristics of protistan control of bacterial production in three reservoirs of different trophy. Int Rev Hydrobiol (Spec Issue) 83:485-494

Šimek K, Babenzien D, Bittl T, Koschel R, Macek M, Nedoma J, Vrba J (1998b) Microbial food webs in an artificially divided acidic bog lake. Int Rev Hydrobiol 83:3-18

Šimek K, Kojecká P, Nedoma J, Hartman P, Vrba J, Dolan JD (1999) Shifts in bacterial community composition associ-

Editorial responsibility: John Dolan,

Edgewater, Maryland, USA ated with different microzooplankton size fractions in a eutrophic reservoir. Limnol Oceanogr 44:1634-1644

Skibbe O (1998) Die Rolle planktischer Ciliaten im Nahrungsnetz eines hypertrophen Sees (Heiligensee, Berlin). PhD thesis, Freie Universität Berlin

Skogstad A, Granskog L, Klaveness D (1987) Growth of freshwater ciliates offered planktonic algae as food. J Plankton Res 9:503-512

Smits JD, Riemann B (1988) Calculation of cell production from $\left[{ }^{3} \mathrm{H}\right]$ thymidine incorporation with freshwater bacteria. Appl Environ Microbiol 54:2213-2219

Stabell T (1996) Ciliate bacterivory in epilimnetic waters. Aquat Microb Ecol 10:265-272

Tamar H (1979) The movements of jumping ciliates. Arch Protistenkd 122:290-327

Tamar H (1990) Halteria bifurcata Tamar, 1968, distribution and variation, and Halteria grandinella O. F. Müller, 1773. Arch Protistenkd 138:3-15

Taylor WD (1978) Maximum growth rate, size and commonness in a community of bactivorous ciliates. Oecologia 36: $263-272$

Thouvenot A, Richardot M, Debroas D, Devaux J (1999) Bacterivory of metazooplankton, ciliates and flagellates in a newly-flooded reservoir. J Plankton Res 21:1659-1679

Vaqué D, Gasol JM, Marresé C (1994) Grazing rates on bacteria: the significance of methodology and ecological factors. Mar Ecol Prog Ser 109:263-274

Vidal A, Om J (1993) The eutrophication process in Sau Reservoir (NE Spain): a long term study. Verh Int Verein Limnol 25:1247-1256

Weisse T (1993) Dynamics of autotrophic picoplankton in marine and freshwater ecosystems. Adv Microb Ecol 13: $327-370$

Wiackowski K, Brett MT, Goldman CR (1994a) Differential effects of zooplankton species on ciliate community structure. Limnol Oceanogr 39:486-492

Wiackowski K, Doniec A, Fyda J (1994b) An empirical study of the effect of fixation on ciliate cell volume. Mar Microb Food Webs 8:59-69

Wilbert N (1969) Ökologische Untersuchung der Aufwuchsund Planktonciliaten eines eutrophen Weihers. Arch Hydrobiol Suppl 35:411-518

Submitted: November 22, 1999; Accepted: May 3, 2000 Proofs received from author(s): June 19, 2000 